\title{
LIGNIN STUDIES
}

\section{Lignin as tracer in digestibility investigations}

\author{
Maija-LiIsa Salo \\ Department of Animal Nutrition and Husbandry, University of Helsinki
}

Received March 14, 1958

The digestibility of foods can be determined both by conventional digestion trials and by the ratio technique. In the latter method an indigestible reference material is fed to the animal and the digestibility coefficients are calculated from the ratios of the nutrients and the reference material in the food and in the faeces. The ratio method eliminates the necessity of making total collections, permits digestion trials to be conducted in ordinary barn stalls, and saves time, labor, and expense.

Chromic oxide, proposed as tracer by EDIN (7), is the most common used reference substance. Iron oxide (4), and plant pigments (23) have been used by some investigators. Already in 1926 PaLOHEImo (21) pointing out the indigestibility of lignin suggested the possibility of using lignin as tracer in digestibility determinations of coarse fodders. In recent years the lignin ratio technique has attracted a number of investigators.

The lignin determination method of Ellis et al. (8), which is most often used in lignin ratio experiments, has been found by some workers to give a satisfactory recovery of lignin. Ellis et al. (8) reported the digestibility of lignin as varying from $-6.0 \pm 1.08$ to $+6.0 \pm 1.82 \%$ for cows fed on mixed food or grass. SwrFt et al. (29) found it rangeing from -6.2 to $+5.2 \%$ when different foods were given. KANE et al. (15) report that no significant difference exists between the digestibility coefficients obtained by the use of lignin ratio and those calculated by the standard total collection procedure. Adolph et al. (1) found the digestibility of lignin in alfalfa varying from $+2.1 \pm 3.4$ to $+8.2 \pm 3.6 \%$ and ForBEs et al. (10) stated the digestibility of lignin in a clover-timothy hay as being $-1.0 \pm 2.6 \%$. ForBes and GARRIGUS (11) report that in a series of seven digestion trials with steers fed on freshly cut grass the avarage recovery of lignin was $102 \pm 7 \%$. In later trials, however, FORBES and GARRIGUS (12) found significant negative digestion coefficients when green forages were given. The lowest values were $-18 \%$ with steers and $-27 \%$ with wethers. In the experiments of ELY et al. (9) the cows received orchard grass hay 
harvested at four stages of maturity plus grain. The digestibility coefficients of crude lignin ranged from 3.8 to $16.0 \%$ and of lignin corrected for its nitrogen content from 7.5 to $19.8 \%$. Miller et al. (16) found that the digestibility of lignin from various grasses varied from +2.8 to $+9.1 \%$ while that from clover was +21.7 and $+26.4 \%$.

The modifications of the method of Ellis et al. have given even more diverse results than those mentioned above $(24,28)$. Such is also in general the case when some other methods have been used $(14,25,18,6)$. However, Balch et al. (3) by using the method of ARMitAGE et al. (2) found the digestibility of lignin to be $+1.3 \pm$ $0.75 \%$ for cows fed on hay and concentrates.

In this laboratory lignin has been used as tracer in investigations concerning the transport of food in the alimentary canal and the extent of digestion in different parts of the alimentary tract $(20,17)$. The lignin was determined by three modifications (a, b, c) of the method (method A) described in a previous paper (26). This method includes a protein correction for crude lignin. The difference between these three method modifications concerns only the treatment with strong acid and has no appreciable influence on the lignin values.

\section{Experimental and results}

The object of this investigation was to determine the digestibility of lignin when the different modifications of the method were used. The samples of hay and of corresponding faeces were obtained from experiments carried out with wethers in the Department of Animal Husbandry, Agricultural Research Centre, Tikkurila. The results are given in Table 1. The four first samples of hay are cut in the haying season, the last one is cured after blooming. No significant differences could be seen in the various modifications of the methods used. The digestibility of lignin varies

Table 1. Digestibility coefficient for lignin of timothy-clover hay cut at haying season,

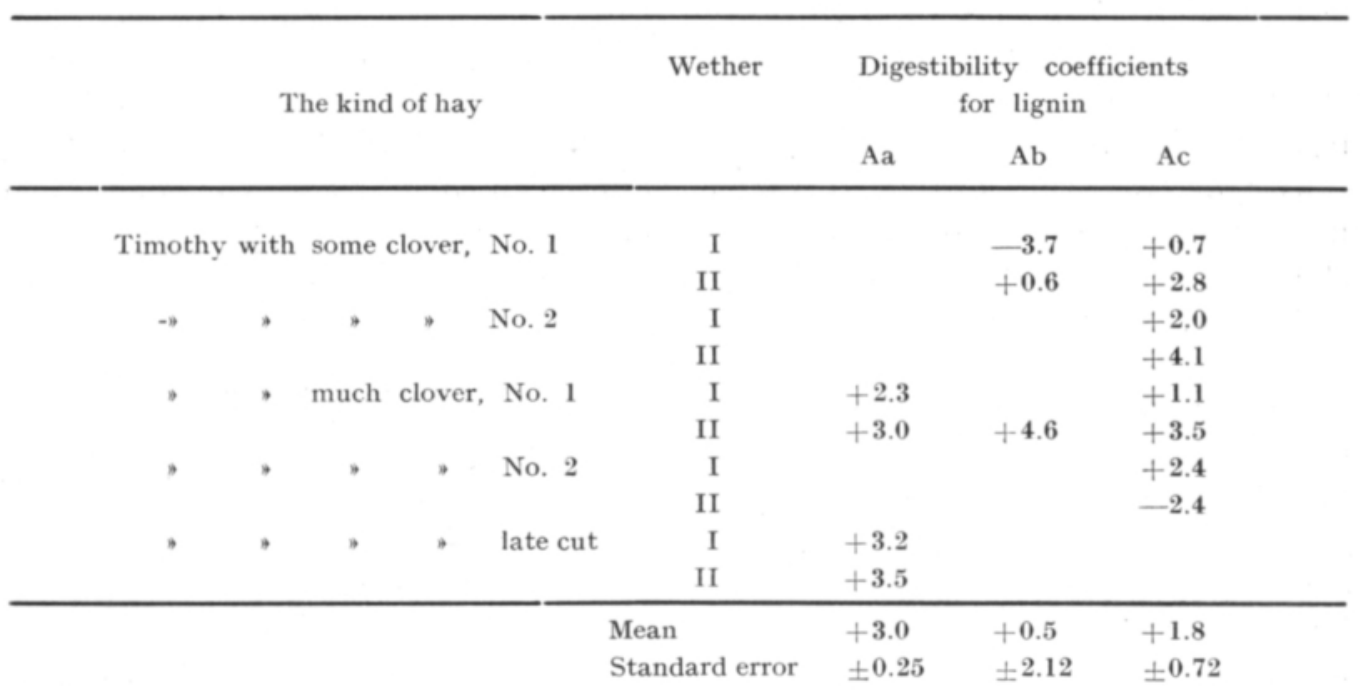


from -3.7 to $+4.6 \%$ and the avarage value in these 15 experiments is $+1.8 \pm$ $0.6 \%$. Such a digestibility of tracer causes an error of $1-1 \frac{1}{2} \%$ for the digestibility coefficients of nutrients.

A comparison was also made between the digestibility coefficients of lignin determined by method $\mathrm{A}$ and by its modification completed with pepsin digestion (method B) described in the earlier paper (26). The results are given in Table 2. Compared with method A, method B gives somewhat lower lignin values for materials rich in protein and poor in membrane substances. The values in Table 2 show that by method A a lower digestibility is obtained for lignin than for crude lignin. Differences are significant. However, with method B the digestibility of crude lignin is somewhat lower than that of lignin. The avarage digestibility of lignin with method $\mathrm{A}$ is $+1.8 \pm 0.7 \%$ and that of crude lignin with method $\mathrm{B}+3.1 \pm 0.9 \%$. Thus the lignin determined by method $\mathrm{A}$ is somewhat better for the lignin ratio technique than the crude lignin determined by method B. On the other hand, method B saves labor, because a determination of the nitrogen content of crude lignin is not needed.

Some determinations were also made on the digestibility of lignin from hays cut at an early stage of development. The lignin was determined by method A. The results, given in Table 3, differ significantly from those obtained from more mature hay. The digestibility of lignin varies from +13.1 to $+23.2 \%$ with the average value of $17.6 \pm 1.0 \%$. This indicates that the lignin ratio technique is not suitable for investigations concerning immature hay, at least when lignin is determined by the type A method.

The high digestibility coefficients may be caused by the fact that a part of the lignin is really digestible. As is known (26) the lignin in timothy and in red clover at different stages of growth varies in its methoxyl content and it is of course possible that it varies also in digestibility. Some investigators $(22,27)$ report increased urinary

Table 2. Digestibility coefficients for lignin and crude lignin of hay, by using two different lignin determination methods.

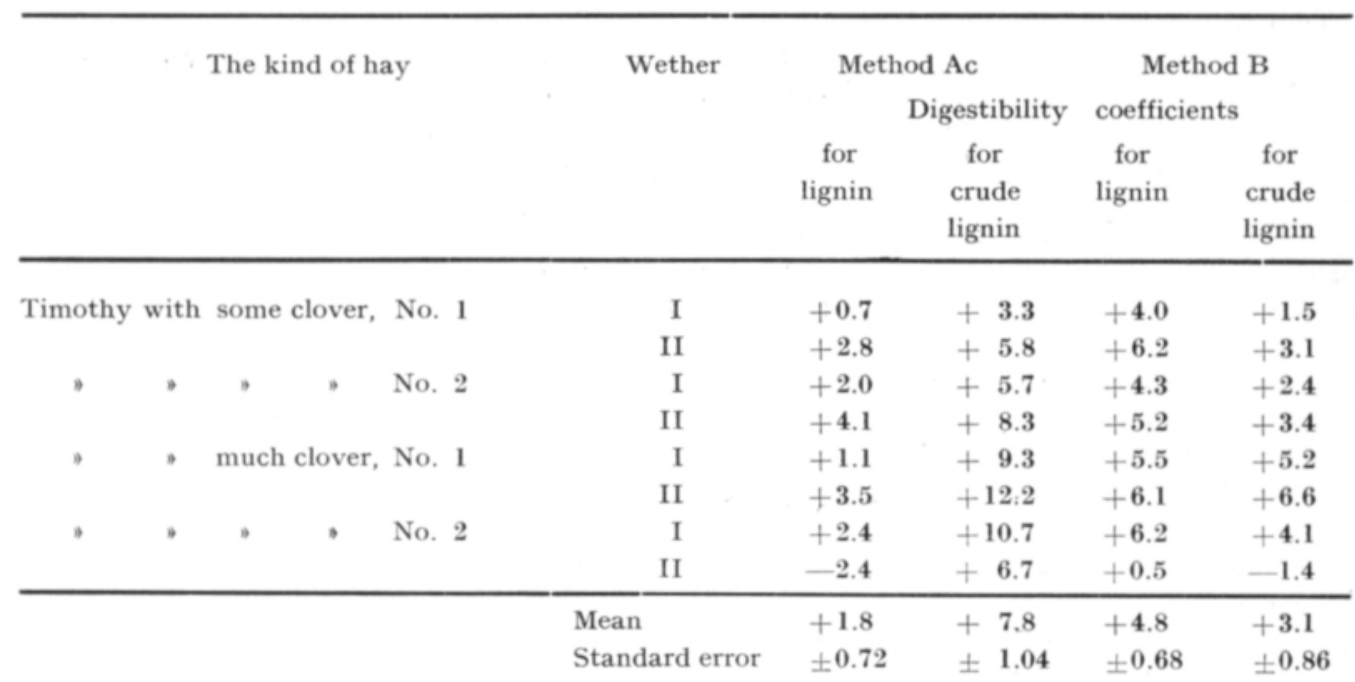


Table 3. Digestibility coefficients for lignin of timothy and red clover hay cut at early stage of growth.

\begin{tabular}{|c|c|c|c|c|c|}
\hline \multirow{2}{*}{\multicolumn{3}{|c|}{ The kind of hay }} & \multirow[t]{2}{*}{ Wether } & \multicolumn{2}{|c|}{$\begin{array}{c}\text { Digestibility coefficients } \\
\text { for lignin } \\
\text { Method }\end{array}$} \\
\hline & & & & $\mathrm{Aa}$ & Ac \\
\hline \multirow[t]{2}{*}{ Timothy with } & some clover & & I & +15.2 & \\
\hline & & & II & +15.3 & \\
\hline \multirow[t]{2}{*}{, } & much clover, & No. 1 & I & +19.8 & \\
\hline & & & 11 & +19.5 & \\
\hline \multirow[t]{2}{*}{, } & , & No. 2 & I & +17.6 & \\
\hline & & & II & +16.4 & \\
\hline \multirow{3}{*}{\multicolumn{3}{|c|}{ Red clover, early leaf stage }} & I & & +13.7 \\
\hline & & & II & & +14.4 \\
\hline & & & III & & +13.1 \\
\hline \multirow{3}{*}{\multicolumn{3}{|c|}{ Red clover, leaf stage }} & I & & +22.2 \\
\hline & & & II & & +23.2 \\
\hline & & & III & & +21.2 \\
\hline & & & & +17.3 & +18.0 \\
\hline & & & indard error & \pm 0.82 & \pm 1.92 \\
\hline
\end{tabular}

Table 4. Methoxyl content of lignin, and crude protein $(6.25 \times \mathrm{N})$ content of crude lignin in the contents of different parts of alimentary tract of cows.

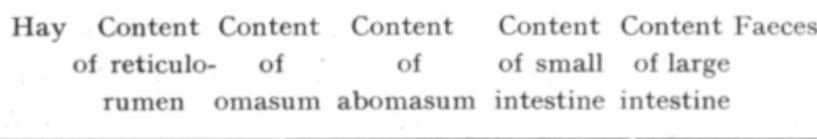

Cow 1 .

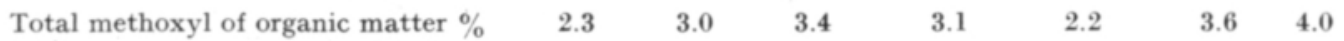

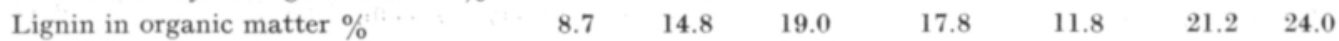

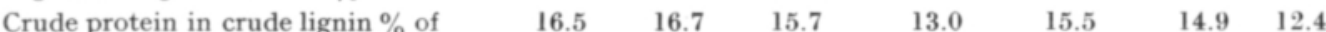

crude lignin $\ldots$

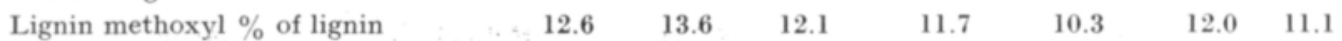

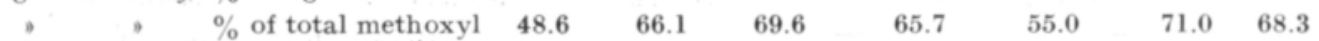

Losses of total methoxyl $\%$
of lignin $\quad \%$

$\begin{array}{llllll}20.0 & 33.3 & 32.3 & 28.0 & 34.0 & 37.5\end{array}$

$-7.9 \quad 4.0$

$\begin{array}{ll}7.1 & 18.3\end{array}$

$4.8 \quad 11.9$

Cow 2.

Lignin in organic matter \%

Crude protein in crude lignin $\%$ of

7.

21. crude lignin

Lignin methoxyl \% of lignin

Losses of lignin methoxyl \%

$7.9^{-\cdots}-13.4$

16.6

$\begin{array}{rrrr}11.6 & 11.9 & 18.3 & 21.0 \\ 16.2 & 17.2 & 16.8 & 14.0 \\ & & & \\ 11.8 & 10.2 & 11.5 & 11.5 \\ 8.5 & 20.9 & 10.9 & 10.9\end{array}$

Cow 3.

Lignin in organic matter \%

Crude protein in crude lignin \% of

$14.5 \quad 18.1$

14.4

12.5

$20.9 \quad 22.8$

21.3

20.1

18.6

15.6

16.4

$16.9 \quad 14.4$

crude lignin

12.9 
excretion of hippuric acid per $100 \mathrm{~g}$ lignin of food when less mature hay is fed and suppose the excretion of benzoic acid to indicate a metabolism of lignin in the animal body.

However, there is every probability that the high positive digestibility coefficients (as well as the negative coefficients found by some workers) are at least partially caused by the faults in the methods used. At least the variability of methoxyl percentages in lignin preparations obtained from the food and from the contents of different parts of the alimentary tract reveals differences in the chemical structure of those preparations. The figures in Table 4 are instructive in this respect.Lignin was determined by method A and methoxyl by a modification of the Zeisel method (19). The digestibility of total methoxyl was calculated by the lignin ratio technique. The results show that the main portion of the digestible total methoxyl disappears in the proventriculi. The methoxyl content of lignin varies in the contents of different parts of the alimentary tract, but any regular decrease cannot be seen. Most exceptional are the lignin methoxyl values from the contents of the small intestine. The losses of lignin methoxyl in the whole alimentary canal vary in these three cows from 10.1 to $11.9 \%$. Much higher losses have been found by some investigators. CsonKa et al. (5) report that $37 \%$ of the methoxyl groups of a lignin preparation obtained from corn cobs by the alkali method, disappeared in the digestive tract of a cow. Francors et al. (13) found that lignin from alfalfa suffered a loss of $50 \%$ of the methoxyl groups in passing through the digestive tract of ruminants. ElY et al. (9) report that the losses of the lignin methoxyl groups ranged from 20.3 to $31.6 \%$ in cows fed on alfalfa. In the experiments of Ely et al. the lignin in hay and corresponding faeces differs only a little in its methoxyl content yet they have taken the digestibility of lignin into account in the calculation. In the experiment concerned in Table 4 lignin was considered to be indigestible. When the digestion of lignin methoxyl was calculated from the weights of lignin methoxyl consumed and excreted, it was found that the digestibility coefficient for lignin methoxyl varied to some extent with the method used in the lignin isolation. When the method included a lipid extraction, pepsin digestion, refluxing in dilute acid before and after the hydrolysis in 72 per cent sulphuric acid, a digestibility coefficient of about $+6 \%$ was obtained. The losses of lignin methoxyl may be due 1) to the partial demetylation of lignin in the digestive tract, 2) to variable losses of methoxyl in the preparation of lignin or 3) to the remaining variable amounts of non-lignin methoxyl in preparations.

In Table 4 are given also the crude protein percentages $(6.25 \times \mathrm{N})$ of crude lignin in the contents of different parts of the alimentary tract of three cows fed on hay with timothy predominating. The nitrogen content of crude lignin is highest in hay and lowest in feaces. However, when lignin is isolated by method B (26) the nitrogen content of crude lignin is somewhat higher in the faeces than in hay, because the pepsin pretreatment significantly lowers the nitrogen content of the lignin from hay but has only negligible influence on that from faeces. The correction of crude lignin for its nitrogen content does not in every case improve the suitability of lignin as tracer as can be seen in Table 2. The same has been observed also by some other investigators $(9,3)$. 
Further, traces of furfurol were obtained from the lignin isolated from hay but not from the lignin of faeces. There is also an evident physical differencebetween the lignin preparations from hay and those from corresponding faeces, e.g. the filtration of crude lignin from hay is considerably slower than that from faeces.

All the above goes to show that lignin is rather a conventional reference substance. The method $\mathrm{A}$ is useful for the lignin ratio technique in investigations concerning mature hay or hay cured after blooming, which contains lignin about $7 \%$ or more. However, if the lignin content of the food is below $6 \%$, it is convenient to establish the validity of the method with a digestion trial.

\section{$S u m m$ ary}

The suitability of lignin as a tracer substance, i.e. the apparent indigestibility of lignin, is dependent on the method used for the determination of lignin. Further, a method suitable for one food is not necessarily suitable for all kinds of food.

By the method used in this investigation (method A) the mean digestibility of lignin from mature hay or from hay cured after blooming was found to be $+1.8 \pm$ $0.6 \%$. However, the mean digestibility of lignin from hay cut at an early stage of growth was $+17.6 \pm 1.0 \%$.

When a pepsin pretreatment was included in the method (method B) the digestibility of crude lignin was found to be somewhat lower than the digestibility of lignin. The lignin determined by method A is more suitable for the lignin ratio technique (digestibility coefficient $+1.8 \pm 0.7$ ) than the crude lignin determined by method $\mathrm{B}$ (digestibility coefficient $+3.1 \pm 0.9$ ).

The lignin preparations isolated from hay and from corresponding faeces have not a uniform composition. Appreciable differences appear in the methoxyl and in the nitrogen contents.

Acknowledgement. The author wishes to express her gratitude to Prof. Lauri Paloheimo for the valuable help given at all stages of this work.

REFERE N C E :

(1) Adolph, W. H. \& Macdonald, H. A. et al. 1947. Content and digestibility of morning and evening cuttings of alfalfa. J. Anim. Sci. 6:348 - 351.

(2) Armitage, E. R. \& Ashworth, R. D. \& Ferguson, W. S. 1948. The determination of lignin in plant material of high protein content. J. Soc. Chem. Ind. 67: 241-243.

(3) Balch, D. A. \& Balch, C. C. \& Rowland, S. J. 1954. The influence of the method of determination of lignin on the lignin-ratio technique for digestibility in the cow. J. Sci. Food. Agric. 5: $584-588$.

(4) Bergeim, O. 1926. Intestinal chemistry. IV. A method for the study of food utilization of digestibility. J. Biol. Chem. 70: 29-33.

(5) Csonka, F. A. \& Phillips, M. \& Jones, D. B. 1929. Studies on lignin metabolism. J. Biol. Chem. 85: $65-75$.

(6) Davis, R. E. \& Miller, C. O. \& Lindahl, I. L. 1947. Apparent digestibility by sheep of lignin in pea and lima-bean vines. J. Agric. Res. 74: 285-288. 
(7) EDIN, H. 1926. Fortsatta försök med indirekta på ıledkroppsprincipen grundade metoder för bestämning av fodrets smältbarhet. Medd. N:r 309 Centr. anst. förs. väsendet jordbr. området. Husdj. avd. N:r 50: 1-79.

(8) Ellis, G. H. \& Matrone, G. \& Maynard, L. A. 1946. A 72 percent $\mathrm{H}_{2} \mathrm{SO}_{4}$ method for the determination of lignin and its use in animal nutrition studies. J. Anim. Sci. 5: 285-305.

(9) Ely, R. E. \& KAnE, E. A. et al. 1953. Studies on the composition of lignin isolated from orchad grass hay cut at four stages of maturity and from the corresponding feces. J. Dairy Sci. $36: 346-355$.

(10) Forbes, E. B. \& Elliot, R. F. et al. 1946. Variation in determination of digestive capacity of sheep. J. Anim. Sci. 5: $298-305$.

(11) - - \& GARrigus, W. P. 1948. Application of a lignin ratio technique to the determination of the nutrient intake of grazing animals. Ibid. $7: 373-382$.

(12) —— \& GARrigus, W. P. 1950. Some effects of forage composition on its nutritive value when cut and feed green to steers and wethers, as determined conventionelly and by the lignin ratio. Ibid. 9: 531-539.

(13) Francois, A. \& Leroy, A. M. \& Lery, G. 1951. The fate of methoxyl groups during digestion of pectin and lignin by ruminats. Compt. rend. 232: 1323-1325. (Ref. Chem. Abstr. 45: 8099.)

(14) Hale, E. B. \& Duncan, C. W. \& Huffman, C. F. 1940. Rumen digestion in the bovine with some observations on the digestibility of alfalfa hay. J. Dairy Sci. 23: 953-967.

(15) Kane, E. A. \& Jacobson, W. C. \& Moore, L. A. 1950. A comparison of techniques used in digestibility studies with dairy cattle. J. Nutr. 41: 583-596.

(16) Miller, W. J. \& Waugh, R. K. \& Matrone, G. 1954. Comparison of the digestibility of certain pasture forages in the fresh and dried states. J. Anim. Sci. 13: 283-288.

(17) MÄKel Ä, A. 1956. Studies on the question of bulk in the nutrition of farm animals with special reference to cattle. Acta agr. fenn. 85: 1-130.

(18) Nehring, K. \& L.aube, W. 1955. Untersuchungen über die Zusammensetzung der pflanzlichen Gerüstsubstanz in Grün- und Rauhfutterstoffen und ihren Einfluss auf die Verdaulichkeit dieser Futterstoffe. Arch. Tierernähr, 5: 177-215.

(19) Official methods of analysis of the association of official agricultural chemists. p. 744. Wisconsin 1950.

(20) Paloheimo, L. \& Mäkelä, A. \& Salo, M.-L. 1955. Some quantitative data on the role of the ruminant proventriculi in the digestion and absorption of nitrogen-free organic matter. J. Scient. Agric. Soc. Finl. 27: 70-76.

(21) PAlohermo, L. 1926. Lignin determination by acid hydrolysis. 62 p. Helsinki.

(22) PAzur, J. H. \& Delong, W. A. 1948. Effect of lignin content and of stage of maturity of dry clover forage on the urinary excretion of aromatic acids by sheep. Sci. Agric. 28: $39-46$.

(23) Reid, J. T. \& Woolfolk, P. J. et al. 1949. A new indicator method for the determination of digestibility and consumption of forages by ruminants. J. Anim. Sci. 8: 636.

(24) Richards, C. R. \& REID, J. T. 1952. The use of methoxyl groups in forage and fecal materials as an index of the feeding value of forages. J. Dairy Sci. 35: 595-602.

(25) Rutledge, W. A. \& Common, R. H. 1947. The composition and digestibility of Northern Irish hays. I. Unthreshed and threshed ryegrass and crested dogstail, bays as saved for seed. J. Agric. Sci. 37: 60-63.

(26) Salo, M.-L. 1957. Lignin studies. I. Investigations concerning the lignin determination. J. Scient. Agric. Soc. Finl. 29: 185-193.

(27) Sjollema, B. \& Lehr, J. J. 1942. Estimation of the nutritive value of pasture by chemical analysis. Landb. Tijdschr. 1942: 69-87. (Ref. Chem. Abstr. 44: 4163).

(28) Sullivan, J. T. 1955. Cellulose and lignin in forage grasses and their digestion coefficients. J.Anim. Sci. 14: $710-717$.

(29) Swift, R. W. \& Thacker, E. J. et al. 1947. Digestibility of rations for ruminants as affected by proportions of nutrients. Ibid. 6: 432-444. 
S E L O T U S :

\title{
Ligniinitutkimuksia
}

III. LIGNIINI JOHTOAINEENA SULAVUUSTUTKIMUKSISSA

\author{
Maija-Liisa Salo
}

Yliopiston kotieläintieteen laitos, Helsinki

Koska ligniini on rehuissa runsaimmin esiintyvistä aineista huonoimmin sulava, joissakin tapauksissa ehkä kokonaan sulamaton, on sitä ryhdytty käyttämään johtoaineena sulavuustutkimuksissa, jolloin rehun eri aineosien sulavuuskertoimet lasketaan rehun ja sonnan välistä ligniinisuhdetta hyväksi käyttäen. Edellytyksenä ligniinin kelpoisuudelle johtoaineeksi on, paitsi sulamattomuus, riittävän tarkka ja periaatteellisesti oikea määritysmenetelmä. Tällaiselta menetelmältä olisi vaadittava, että suoritettaessa määrityksiä toiselta puolen rehusta ja toiselta puolen vastaavasti sonnasta saadaan kummassakin tapauksessa määritetyksi sama aine. Käytännössä olevat ligniinin määritysmenetelmăt eivät täysin tãytä tätä vaatimusta. Tästä ilmeisestikin johtuu, että eri määritysmenetelmiä käytettäessä saadaan ligniinille erilainen sulavuus. Kotieläintieteen laitoksessa käytetyllä menetelmällä on normaaliaikaan korjatun heinän ligniinin sulavuudeksi saatu $+1.8 \pm 0.6 \%$, kun taas heinän ollessa varhaisella kasvuasteella korjattua saatiin sulavuuskerroin $+17 \pm 1.0 \%$. Näyttää siis siltä, ęttä ligniini ei sovi johtoaineena käytettäväksi silloin, kun on kysymyksessä nuoren ruohon sulavuuden mäărittäminen. Heinästä ja vastaavasta sonnasta eristetyt ligniinipreparaatit eivät osoittautuneet koostumukseltaan täysin samanlaisiksi. Merkittävin ero havaittiin metoksyylipitoisuudessa sekä raakaligniinin typpipitoisuudessa. 